Revista Brasileira de Farmacognosia Brazilian Journal of Pharmacognosy 22(3): 522-527, May/Jun. 2012

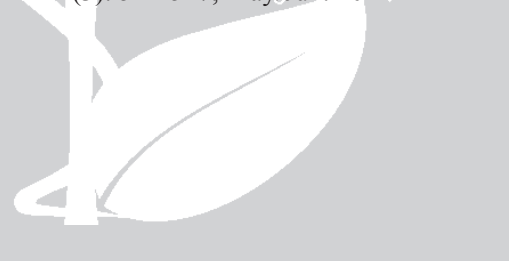

Article

Received 23 Jun 2011

Accepted 3 Oct 2011

Available online 17 Jan 2012

Keywords:

cervix

Croton nepetifolius

muscle relaxant

ovine

ISSN 0102-695X

http://dx.doi.org/10.1590/S0102-

695X2012005000011

\section{Relaxant effect of the essential oil of Croton nepetifolius on ovine cervix}

\author{
Alexsandra F. Pereira, ${ }^{* 1}$ Luciana M. Melo, ${ }^{1}$ Selene M. Morais, ${ }^{2}$ \\ José H. Leal-Cardoso, ${ }^{3}$ Vicente J. F. Freitas ${ }^{1}$
}

\author{
${ }^{1}$ Laboratório de Fisiologia e Controle da Reprodução, Faculdade de Veterinária, \\ Universidade Estadual do Ceará, Brazil, \\ ${ }^{2}$ Laboratório de Química de Produtos Naturais, Universidade Estadual do Ceará, \\ Brazil, \\ ${ }^{3}$ Laboratório de Eletrofisiologia, Instituto Superior de Ciências Biomédicas, \\ Universidade Estadual do Ceará, Brazil.
}

\begin{abstract}
We investigated the in vitro effect of the essential oil of Croton nepetifolius Baill., Euphorbiaceae (EOCN), on spontaneous or induced contractions of circular and longitudinal muscles from the ovine cervix during the luteal phase of the estrous cycle. The relaxant effect of EOCN was expressed as a percentage of the contraction recorded before the addition of the oil and calculated relative to the preparations exposed only to the vehicle. The IC50 (concentration of oil required to produce a $50 \%$ maximal reduction in muscle contraction) for relaxation of spontaneous contractions in circular and longitudinal muscles was significantly lower than the IC50 for blockade of $\mathrm{K}^{+}$induced contraction $\left(27.19 \mu \mathrm{g} \mathrm{mL}^{-1}\right.$ versus $262.72 \mu \mathrm{g} \mathrm{mL}^{-1}$ and $40.92 \mu \mathrm{g} \mathrm{mL}^{-1}$ versus $222.47 \mu \mathrm{g} \mathrm{mL}^{-1}$, respectively). Interestingly, there was a high degree of selectivity in the action of EOCN on cervix layers concerning the inhibition of acetylcholine-induced contraction in circular (IC50 $277.10 \mu \mathrm{g} \mathrm{mL}^{-1}$ ) and longitudinal (IC50 $52.56 \mu \mathrm{g} \mathrm{mL}^{-1}$ ) muscles. In conclusion, EOCN is able to relax ovine cervix during the luteal phase. This work opens the perspective of applying EOCN in ovine embryo transfer.
\end{abstract}

\section{Introduction}

Multiple Ovulation and Embryo Transfer (MOET) is a reproductive biotechnology in farming that is used in females of high genetic value, for the purpose of rapidly multiplying the number of their descendents, in a short time span, resulting in the genetic and productive enhancement of the herd (Ishwar \& Memon, 1996). MOET is commercially used in sheep industry and depends on the surgical recovery of embryos, where the principal disadvantage is the limited number of times a female donor can be used (Naqvi et al., 2001).

The non-surgical recovery of embryos, performed through the cervix, is still not readily available for application in ewes. This is due to the physical barrier, that is, the tortuous nature of the cervical canal (Dun, 1955), as well as by the size and shape of the external cervical os (Kershaw et al., 2005). Sheep cervix relaxation would provide the necessary dilatation to allow non-surgical embryo recovery.

Some in vivo studies have already investigated physical (Campbell et al., 1996), mechanical (WulsterRadcliffe et al., 2004) and hormonal methods (Khalifa et al., 1992; Wulster-Radcliffe et al., 1999; Candappa et al., 2009; Perry et al., 2010) for cervical canal dilatation in ewes. Overall, these attempts produced either little or no cervix penetration. When the method was able to straighten or dilate the cervix, its effects on reproductive parameters (such as fertility) were not fully evaluated.

Our group has investigated the muscle relaxant effect of natural substances from Northeast Brazil native plants. Promising results have been obtained with essential oil of Croton nepetifolius Baill., Euphorbiaceae (EOCN), which acts on tracheal (Magalhães et al., 2003), ileal (Magalhães et al., 2004) and vascular (Magalhães et al., 2008) smooth muscles. Based on these findings, we proposed to investigate the action of EOCN on sheep cervix musculature. In view of the perspectives of using this oil for the cervical canal dilatation for embryo recovery, which occurs in the luteal phase of the estrous cycle, the present work used only tissues from females at this phase.

\section{Material and Methods}

General

All reagents utilized in the present research were supplied by Sigma Aldrich (MO, USA) or Reagen (Rio de Janeiro, Brazil). All drugs, except EOCN, were dissolved 
in distilled water and added directly to the organ bath. EOCN was dissolved in Tween 80 and modified Tyrode's solution and this solution was added to the organ bath. The maximal concentration of Tween 80 in the tissue superfusion solution was always less than $0.13 \%$.

\section{Extraction and chemical analysis of EOCN}

Leaves of Croton nepetifolius Baill., Euphorbiaceae, were collected in Viçosa-CE (33' $46^{\prime \prime}$ 'S, $41005^{\prime} 42^{\prime \prime} \mathrm{W}$ ) situated in Northeastern Brazil and voucher specimen was deposited in the Herbarium Prisco Bezerra of Universidade Federal do Ceará, Fortaleza-CE, Brazil, under number 3185. The identification of the plant was performed by Dr. Afranio Fernandes, Departamento de Biologia, Universidade Federal do Ceará, Brazil. EOCN was extracted by steam distillation of fresh leaves (Craveiro et al., 1976) and analyzed using a Shimadzu QP-2010 instrument under the following conditions: column: DB-5ms (Agilent, part No. 122-5532) fused silica capillary column ( $30 \mathrm{~m}$ x $0.25 \mathrm{~mm} \times 0.25 \mu \mathrm{m})$; carrier gas: He ( $1 \mathrm{ml} \mathrm{min} \mathrm{m}^{-1}$, in constant linear velocity mode); injector temperature: $250{ }^{\circ} \mathrm{C}$, in split mode $(1: 100)$; detector temperature: $250{ }^{\circ} \mathrm{C}$; column temperature programming: $35-180{ }^{\circ} \mathrm{C}$ at $4{ }^{\circ} \mathrm{C} \mathrm{min}^{-1}$ then $180-280{ }^{\circ} \mathrm{C}$ at $17^{\circ} \mathrm{C} \mathrm{min}^{-1}$ and at $280^{\circ} \mathrm{C}$ for $10 \mathrm{~min}$; mass spectra: electron impact $70 \mathrm{eV}$. The injected sample volume was $1 \mu \mathrm{L}$. The constituents were identified by their gas chromatography (GC) retention times relative to known compounds and expressed by Kovat Index, which were calculated by linear regression, and by comparison of their mass spectra (MS) with those present in the computer data bank (National Institute for Standard Technology-NIST-147 198 compounds) and published spectra (Adams, 2007).

\section{Animals and tissue collection}

Cycling adult ewes $(n=14)$ aged 30.0 $\pm 3.4(X \pm S E)$ months were obtained from local abattoir (Guaiuba Agropecuária S/A, Guaiuba-CE), which is inspected by a state service for control of animal origin products. In this establishment, sheep management (reception, maintenance and slaughter by captive bolt) follows the standard rules for humane slaughter of animals (Normative n. 3: 17/01/2000Ministério de Agricultura Pecuária e AbastecimentoMAPA). The cervix was removed and transported to the laboratory in modified Tyrode's solution (in $\mathrm{mM}: \mathrm{NaCl}$ 136.0, $\mathrm{KCl} 5.0, \mathrm{CaCl}_{2} 2.0, \mathrm{MgCl}_{2} 0.98, \mathrm{NaH}_{2} \mathrm{PO}_{4} 0.36$, $\mathrm{NaHCO}_{3} 11.9$ and glucose 5.5, $\mathrm{pH} 7.4$ ), at $5{ }^{\circ} \mathrm{C}$ within $2-3$ h. After confirming the absence of pregnancy, the ovaries were removed and macroscopically examined to determine the phase of the estrous cycle (Pereira et al., 2007). The only tissues used were those from animals showing at least one corpus luteum, thereby characterizing the luteal phase.
Tissue preparations, measurements of contractility and recording of data

The tissue strips were prepared according to methods previously described by Pereira et al. (2007). Thus, muscle segments (4-5 mm wide, 9-10 mm long and $1 \mathrm{~mm}$ thick) corresponding to circular and longitudinal fibers were suspended vertically in an organ bath containing $5 \mathrm{~mL}$ modified Tyrode's solution, at $37{ }^{\circ} \mathrm{C}$, bubbled continuously with air. The tissue segments were loaded with an initial tension of $1 \mathrm{~g}$ and allowed to equilibrate for $60 \mathrm{~min}$ to establish reproducible spontaneous contractility. The segments were attached to a hook and to an isometric force transducer (Grass Instruments, MA, USA) connected by a transducer cable (Grass Instruments, MA, USA) to a 4-channel polygraph chart recorder (Grass Instruments, MA, USA). All signals from the force transducers were recorded and stored in a computerized system (DATAQ Instruments, OH, USA).

The activity was evaluated in each circular and longitudinal cervical layers on: (i) spontaneous contractions (EOCN: 0.1-1000 $\mu \mathrm{g} \mathrm{mL}^{-1}$ ), (ii) potassium chloride (KCl)induced contractions (EOCN: 0.1-3000 $\mu \mathrm{g} \mathrm{mL}-1$ ) and (iii) acetylcholine (ACh)-induced contractions (EOCN: 0.1-2000 $\left.\mu \mathrm{g} \mathrm{mL}^{-1}\right)$. Concentration-response curves were obtained from at least five repetitions. In all protocols, control experiments were carried out using only vehicle $(0.13 \%$ Tween 80$)$ substituting EOCN. At beginning and the end of each experiment, the viability of the tissue preparation was tested by inducing at least 2 successive contractions by means of $60 \mathrm{mM} \mathrm{KCl}$, in between two washings with modified Tyrode's solution.

\section{Calculations and statistical analysis}

All data were expressed as mean \pm SE of individual values. The amplitude of spontaneous or induced contractions was determined by measuring the peak height of contraction relative to baseline tonus $(0 \mathrm{~g}$ tension). The tissue responses produced in the presence of EOCN were expressed as percent of spontaneous or induced (by $\mathrm{ACh}$ or $\mathrm{KCl}$ ) contraction previously recorded before the addition of the first concentration of oil. The muscle relaxant effect produced by EOCN in the different tissue layers was evaluated by IC50 values, defined as the concentration of oil required to produce a $50 \%$ maximal reduction in muscle contraction. These values were calculated from the interpolation of the semi-logarithmic curves and non-linear regression analysis of least squares, using the software SigmaPlot 9.0 (Systat, San Jose, USA). The means of the contractions produced in the presence of EOCN or the vehicle were analyzed for statistically significant differences using ANOVA and a post hoc test (Student's t or Mann-Whitney). A probability level of $<0.05$ was considered significant. 


\section{Results and Discussion}

In present study, the muscle relaxant effect of EOCN on the spontaneous contractions of the circular and longitudinal muscle layers of sheep cervix was found to be concentration-dependent (Figure 1). EOCN concentrations higher than $10 \mu \mathrm{g} \mathrm{mL}^{-1}$ significantly inhibited $(p<0.05)$ the amplitude of the spontaneous contractions in the tissues compared to those recorded in tissues exposed only to vehicle (control). In both muscle layers, the oil produced $100 \%$ inhibition of muscle contractions at concentrations greater than $300 \mu \mathrm{g} \mathrm{mL}^{-1}$. The IC50 values calculated for both circular and longitudinal segments did not differ significantly $\left(27.19 \pm 6.35\right.$ and $40.92 \pm 12.41 \mu \mathrm{g} \mathrm{mL} \mathrm{mL}^{-1}$, $p>0.05)$.

Unlike the depressant effect of EOCN on intestinal muscle (Magalhães et al., 1998), no reduction in basal tonus was observed in ewe cervix. On the other hand, the essential oil of Croton zehntneri, a closely related aromatic species of the croton genus (Craveiro et al., 1980) that is similarly used in Northeast Brazil for intestinal disturbances treatment, has either no effect or minimal relaxant effect on the intestine basal tonus (Coelho-deSouza et al., 1997).

EOCN significantly reduced $(p<0.05)$ the muscle contractions induced by $80 \mathrm{mM} \mathrm{KCl}$ at concentrations greater than 300 and $100 \mu \mathrm{g} \mathrm{mL}^{-1}$ in the circular and longitudinal (Figure 2) segments, respectively, in relation to the vehicle. In both muscles layers, the oil produced $100 \%$ inhibition of the contractions induced at concentrations greater than $2000 \mu \mathrm{g} \mathrm{mL}^{-1}$. The IC50 values calculated for circular and longitudinal segments did not differ significantly $(262.72 \pm 8.94$ and $222.47 \pm 53.52 \mu \mathrm{g}$ $\left.\mathrm{mL}^{-1}, p>0.05\right)$.
Despite the high maximal inhibition of both spontaneous and $\mathrm{K}^{+}$-induced contractions in cervical preparations, the IC50 for relaxation of spontaneous contractions in circular and longitudinal muscles was significantly lower than the IC50 for blockade of the $\mathrm{K}^{+}$ contracture $\left(27.19 \mu \mathrm{g} \mathrm{mL}^{-1}\right.$ versus $262.72 \mu \mathrm{g} \mathrm{mL} \mathrm{m}^{-1}$ and $40.92 \mu \mathrm{g} \mathrm{mL}^{-1}$ versus $222.47 \mu \mathrm{g} \mathrm{mL}^{-1}$, respectively). Thus, although it was beyond the scope of the current study, our results allow us to hypothesize that the mechanism of action of EOCN in sheep cervical muscle is probably not myogenic, differing from the report of Magalhães et al. (2004). These authors reported that EOCN induces relaxation of guinea pig ileum by a direct action on smooth muscle via a mechanism largely independent of alterations of transmembrane resting potential and $\mathrm{Ca}^{2+}$ influx, possibly at the level of the contractile apparatus.

The major components of the EOCN, named mono- and sesquiterpenes, such as methyleugenol, 1,8cineole and $\alpha$-terpineol (Craveiro et al., 1980) are reported to be responsible for the bioactivity in smooth muscles (Magalhães et al., 2008). As the essential oil composition can vary widely depending on the moment at which the plants are collected (Morais et al., 2001), the exact quantification of the contribution of each constituent to the overall effect of oil is not possible. The main components of EOCN sample used in the present investigation were $\beta$-E-caryophyllene (27.01\%), methyleugenol (14.09\%) and 1,8-cineole $(12.38 \%)$ (Table 1), which can be attributed to myorelaxant activity observed. Moreover, other constituents of EOCN can make an important contribution to the effects of this essential oil on ovine cervical muscle.
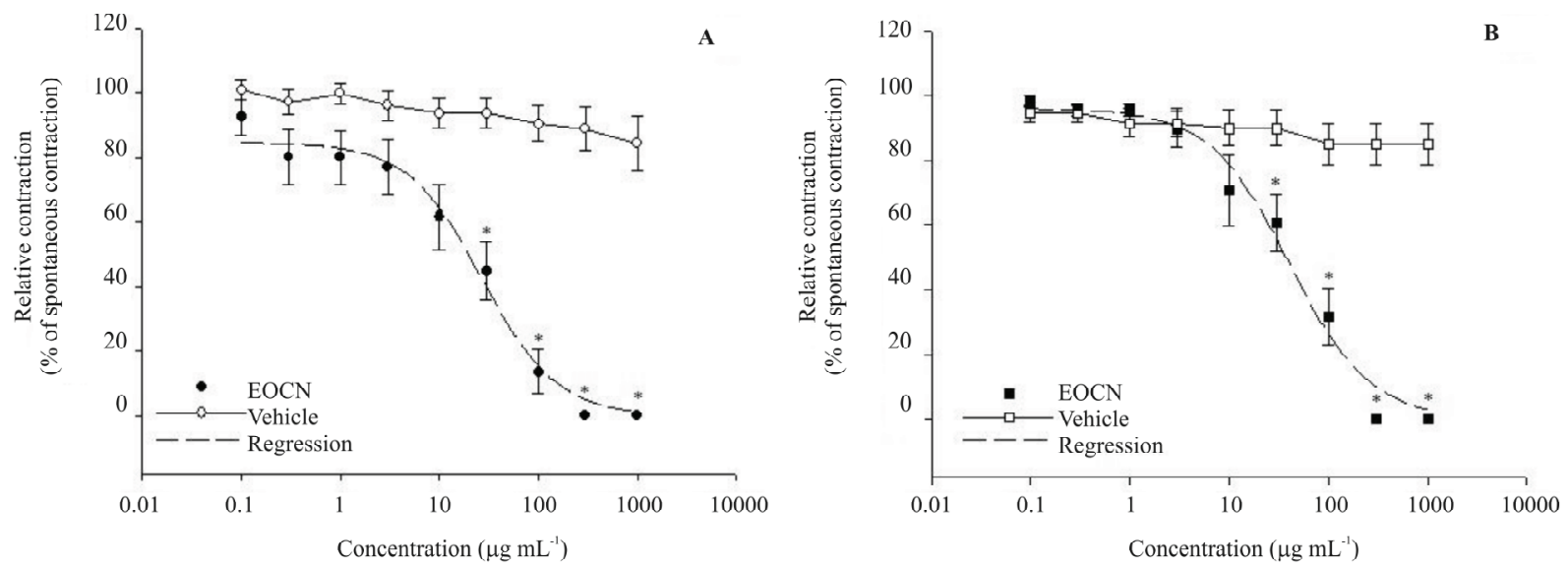

Figure 1. Concentration-dependent inhibitory effects of the essential oil of Croton nepetifolius (EOCN) on the amplitude of the spontaneous contractions in circular (A) and longitudinal (B) smooth muscles of ovine cervix. Data are mean $\pm \mathrm{SE}$ of at least six experiments. *Significant difference $(p<0.05)$ in relation to control contractions (vehicle). 

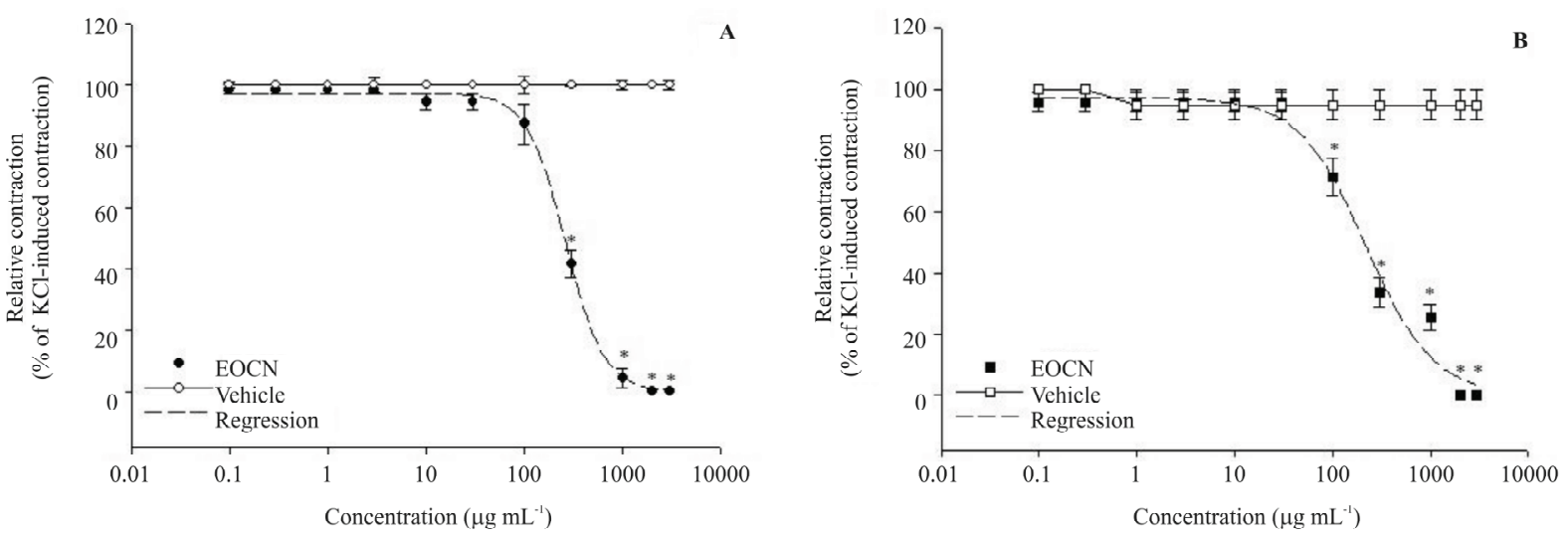

Figure 2. Concentration-dependent inhibitory effects of essential oil of Croton nepetifolius (EOCN) on contractions induced by $80 \mathrm{mM} \mathrm{KCl}$ in circular (A) and longitudinal (B) smooth muscle of ovine cervix. Data are mean $\pm \mathrm{SE}$ of at least five experiments. * Significant difference $(p<0.05)$ in relation to control contractions (vehicle).

Table 1. Chemical composition and retention indices of the constituents of the essential oil of Croton nepetifolius Baill. $(\mathrm{EOCN})$.

\begin{tabular}{ccc}
\hline K.I.* & Compounds & Composition $(\% * *)$ \\
\hline 975 & sabinene & 1.54 \\
1031 & 1,8 -cineole & 12.38 \\
1189 & $\alpha$-terpineol & 2.51 \\
1391 & $\beta$-elemene & 1.42 \\
1404 & methyleugenol & 14.09 \\
1419 & $\beta$-E-caryophyllene & 27.01 \\
1435 & $\alpha$-E-bergamotene & 2.67 \\
1441 & aromadendrene & 1.49 \\
1455 & $\alpha$-humulene & 2.48 \\
1500 & bicyclogermacrene & 6.49 \\
1557 & elemicin & 5.23 \\
1578 & spathulenol & 3.58 \\
1583 & caryophyllene oxide & 5.49 \\
- & Not identified & 13.64 \\
\hline
\end{tabular}

*Kovat Index calculated by linear regression. The identified constituents are listed in their order of elution from a non polar column. ${ }^{* *}$ The $\%$ composition is the \% peak area related to the total essential oil components.

EOCN significantly reduced $(p<0.05)$ the muscle contractions induced by $10 \mu \mathrm{M}$ ACh at concentrations greater than 3 and $100 \mu \mathrm{g} \mathrm{mL} \mathrm{m}^{-1}$, in the circular and longitudinal (Figure 3) segments, respectively, in relation to vehicle. In both muscle layers, the oil produced $100 \%$ inhibition of the contractions induced at concentrations greater than $1000 \mu \mathrm{g} / \mathrm{mL}$. Interestingly, there was a high degree of selectivity in the action of EOCN on cervix layers concerning the inhibition of ACh-induced contractions in circular (IC50 277.10 $\pm 78.82 \mu \mathrm{g} \mathrm{mL}^{-1}$ ) and longitudinal (IC50 52.56 $\pm 14.81 \mu \mathrm{g} \mathrm{mL}^{-1}$ ) musculatures.
Layer-specific differences in pharmacological responses of uterine or cervical muscles have already been reported (Cao et al., 2002). Previously, we found that $10 \mu \mathrm{M}$ prostaglandin $\mathrm{E}_{1}$ reduced the spontaneous contractions of the circular layer in sheep cervix, but had no significant effect on the longitudinal layer in concentrations varying of 0.1-10 $\mu \mathrm{M}$ (Pereira et al., 2007). In the same study, prostaglandin $\mathrm{F}_{2 \alpha}(0.5-30.0 \mu \mathrm{M})$ produced a maximum inhibitory effect of $100 \%$ on spontaneous contractions of longitudinal segments and only $30 \%$ in the circular layers. The variations in responsiveness could be due to different factors, such as distribution and/or concentration of receptors and type of prostaglandin tested (Cao et al., 2002). Both EOCN and prostaglandins presented inhibition spontaneous contractile activity in ovine cervical circular muscles.

The present study shows that EOCN is able to relax ovine cervix during the luteal phase of the estrous cycle, possibly through a non-myogenic mechanism. Finally, this work opens us the perspective of applying EOCN in the embryo transfer industry in sheep. However, in vivo studies must be performed to confirm the in vitro efficacy and to evaluate the possibility of deleterious effects on the embryo.

\section{Acknowledgment}

The authors thank to PADETEC (Ceará, Brazil) for performing the chemical analyses of EOCN. This project was supported by a grant from Pronex-Funcap (Ceará, Brazil). We also thank Dr. A. Leyva for his help with English editing of the manuscript.

\section{References}

Adams RP 2007. Identification of essential oil components by gas chromatography/mass spectrometry. $4^{\circ}$ ed. Illinois USA: 

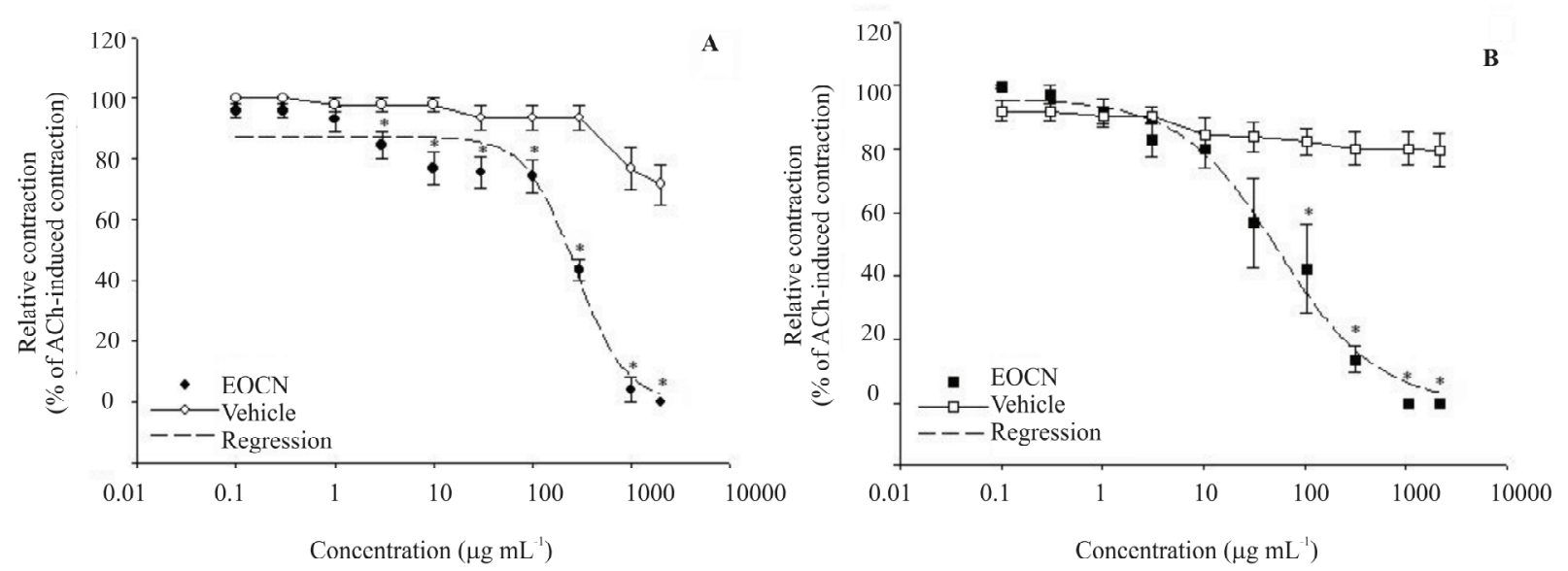

Figure 3. Concentration-dependent inhibitory effects of essential oil of Croton nepetifolius (EOCN) on contractions induced by 10 $\mu \mathrm{M}$ acetylcholine (ACh) in circular (A) and longitudinal (B) smooth muscle of ovine cervix. Data are mean $\pm \mathrm{SE}$ of six experiments. *Significant difference $(p<0.05)$ in relation to control contractions (vehicle).

Allured Publishing Corporation, Carol Stream, 804 p. Campbell JW, Harvey TG, McDonald MF, Sparksmann RI 1996. Transcervical insemination in sheep: an anatomical and histological evaluation. Theriogenology 45: 1535-1544.

Candappa IBR, Bainbridge HC, Price NT, Hourigan KR, Bartlewski PM 2009. A preliminary study on the suitability of Cervidil ${ }^{\circledR}$ to induce cervical dilation for artificial insemination in ewes. Res Vet Sci 87: 204-206.

Cao J, Shayibuzhati M, Tajima T, Kitazawa T, Taneike T 2002. In vitro pharmacological characterization of the prostanoid receptor population in the non-pregnant porcine myometrium. Eur J Pharm Sci 442: 115-123.

Coelho-de-Souza AN, Barata EL, Magalhães PJC, Lima CC, Leal-Cardoso JH 1997. Effects of the essential oil of Croton zehntneri and its constituent estragole on the intestinal smooth muscle. Phytother Res 11: 299-304.

Craveiro AA, Matos FJA, Alencar JW 1976. Simple and inexpensive steam-generator for essential oils extraction. J Chem Educ 53: 562.

Craveiro AA, Andrade C, Matos FJA, Alencar JW, Dantas TNC 1980. Fixed and volatile constituents of Croton aff. nepetaefolius. J Nat Prod 43: 756-757.

Dun R 1955. The cervix of the ewe. Its importance in artificial insemination of sheep. Aust Vet J 31: 101-103.

Ishwar AK, Memon MA 1996. Embryo transfer in sheep and goats: a review. Small Ruminant Res 19: 35-46.

Kershaw CM, Khalid M, McGowan MR, Ingram K, Leethongdee S, Wax G, Scaramuzzi RJ 2005. The anatomy of the sheep cervix and its influence on the transcervical passage of an inseminating pipette into the uterine lumen. Theriogenology 64: 1225-1235.

Khalifa RME, Sayre BL, Lewis GS 1992. Exogenous oxytocin dilates the cervix in ewes. J Anim Sci 70: 38-42.

Magalhães PJC, Criddle DN, Tavares RA, Melo EM, Mota TL, Leal-Cardoso JH 1998. Intestinal myorelaxant and antispasmodic effects of the essential oil of Croton nepetaefolius and its constituents cineole, methyl-eugenol and terpineol. Phytother Res 12: 172-177.

Magalhães PJC, Lahlou S, Vasconcelos dos Santos MA, Pradines TL, Leal-Cardoso JH 2003. Myorelaxant effects of the essential oil of Croton nepetaefolius on the contractile activity of the guinea-pig tracheal smooth muscle. Planta Med 69: 874-877.

Magalhães PJC, Lahlou S, Leal-Cardoso JH 2004. Antispasmodic effects of the essential oil of Croton nepetaefolius on guinea-pig ileum: a myogenic activity. Fund Clin Pharmacol 18: 539-546.

Magalhães PJC, Lahlou S, Juca DM, Coelho-de-Souza LN, Frota PTT, Costa AMG, Leal-Cardoso JH 2008. Vasorelaxation induced by the essential oil of Croton nepetaefolius and its constituents in rat aorta are partially mediated by the endothelium. Fund Clin Pharmacol 22: 169-177.

Morais SM, Machado MIL, Ribeiro VAFA, Militão JSLT, Machado SMF 2001. Seasonal variation of $(E)$-verolidol in Siparuna guianensis Aublet and ${ }^{13} \mathrm{C}-\mathrm{NMR}$ spectral assignments of (E)- and (Z)-nerlidol. J Essent Oil Res 13: 130-131.

Naqvi SMK, Joshi A, Das GK, Mittal JP 2001. Development and application of ovine reproductive technologies: an Indian experience. Small Ruminant Res 39: 199-208.

Pereira AF, Melo LM, Avelar SRG, Moura RM, Leal-Cardoso JH, Freitas VJF 2007. Estrous cycle-dependent differences in responsiveness to prostaglandins and contractile agents in sheep (Ovis aries) cervical smooth muscle. $J$ Vet Pharmacol Therapeut 30: 534-540.

Perry K, Haresign W, Wathes DC, Khalid M 2010. Intracervical application of hyaluronan improves cervical relaxation in the ewe. Theriogenology 74: 1685-1690.

Wulster-Radcliffe MC, Costine BA, Lewis GS 1999. Estradiol$17 \beta$-oxytocin induced cervical dilation in sheep: 
application to transcervical embryo transfer. J Anim Sci 77: 2587-2593.

Wulster-Radcliffe MC, Wang S, Lewis GS 2004. Transcervical insemination in sheep: effects of a new transcervical artificial insemination instrument and traversing the cervix on pregnancy and lambing rates. Theriogenology 62: 990-1002.

\section{*Correspondence}

Alexsandra Fernandes Pereira

Laboratório de Fisiologia e Controle da Reprodução, Faculdade de Veterinária, Universidade Estadual do Ceará

Av. Dedé Brasil 1700, 60740-903 Fortaleza-CE, Brazil alexsandra.fernandes@uece.br

Tel: +558531019861

Fax: + 558531019840 